\title{
Development of hypertension in overweight adolescents: a review
}

This article was published in the following Dove Press journal:

Adolescent Health, Medicine and Therapeutics

21 October 2015

Number of times this article has been viewed

\section{Rebecca K Kelly' \\ Costan G Magnussen ${ }^{1,2}$ \\ Matthew A Sabin ${ }^{3}$ \\ Michael Cheung ${ }^{3}$ \\ Markus Juonala ${ }^{3-5}$}

'Menzies Institute for Medical Research, University of Tasmania, Hobart, Australia; ${ }^{2}$ Research

Centre of Applied and Preventive Cardiovascular Medicine, University of Turku, Turku, Finland; ${ }^{3}$ Murdoch Childrens Research Institute, Royal Children's Hospital and University of Melbourne, Parkville, Australia; ${ }^{4}$ Department of Medicine, University of Turku, ${ }^{5}$ Division of Medicine, Turku University Hospital, Turku, Finland

Correspondence: Rebecca K Kelly Menzies Institute for Medical Research, Private Bag 23, TAS 7001, Australia Tel +6I 402540129 Email rkkelly@utas.edu.au
Abstract: The upward trend in adolescent hypertension is widely attributed to the adolescent obesity epidemic. Secular trends in adolescent prehypertension and hypertension have risen in congruence with increasing trends in the prevalence of overweight and obesity. The correlation between body mass index and blood pressure in adolescence is moderate to strong in most studies and strongest in those classified as overweight or obese. The mechanisms relating to the development of hypertension in overweight adolescents are unclear; however, a number of nonmodifiable and modifiable factors have been implicated. Importantly, certain clinical and biochemical markers in overweight adolescents are indicative of high risk for hypertension, including family history of hypertension and hyperinsulinemia. These characteristics may prove useful in stratifying overweight adolescents as high or low risk of comorbid hypertension. The treatment of overweight and obesity related hypertension in this population focuses on two key modalities: lifestyle change and pharmacotherapy. These approaches focus almost exclusively on weight reduction; however, a number of emerging strategies target hypertension more specifically. Among adolescents with overt hypertension there are also several factors that indicate higher risk of concurrent subclinical disease, persistent adult hypertension, and adult cardiovascular disease. This group may benefit substantially from more aggressive pharmacological treatments. Limitations in the literature relate to the paucity of studies reporting specific effects for the adolescent age group of overweight and obese individuals. Nonetheless, intervention for adiposity-related hypertension in adolescence may partially mitigate some of the cardiovascular risk in adulthood.

Keywords: blood pressure, obesity, prevention, risk factors, childhood

\section{Introduction}

Adolescent overweight and obesity is an issue of epidemic proportions worldwide. ${ }^{1}$ It is estimated that $32 \%$ of adolescents are either overweight or obese. ${ }^{2}$ Increased body mass index (BMI) in adolescence, defined as the period from 10 to 19 years, is strongly associated with morbidity and mortality in adulthood. ${ }^{3,4}$ However, an increasing number of studies suggest that several of these complications are already present during adolescence. Adolescent overweight has been linked to comorbidities such as dyslipidemia, nonalcoholic steatohepatitis, diabetes mellitus type 2, obstructive sleep apnea, and hypertension. ${ }^{5}$

Hypertension is the most common comorbidity identified in overweight adolescents and the leading risk for mortality in adulthood, attributable to approximately $12.8 \%$ of deaths worldwide. ${ }^{6}$ A number of studies have investigated the association between $\mathrm{BMI}$ and blood pressure (BP) in pediatric and adolescent populations, with the majority 
finding moderate to strong associations, with the majority of correlation coefficients $>0.3 .^{7}$ The most recently published investigation was a cross-sectional study of 714,922 subjects aged 16-19 years which demonstrated that each one unit increase in BMI was associated with a higher risk of systolic BP (SBP) greater than $130 \mathrm{mmHg}{ }^{8}$ In view of these data, it is not surprising that secular trends show an increase in adolescent hypertension that parallels the rise in overweight and obesity. These trends challenge the previously held assertion that hypertension in adolescence was only a result of secondary causes such as renal disease. In fact, essential (primary) hypertension now accounts for the vast majority of hypertension identified in adolescence. ${ }^{9}$

As a consequence, overweight-related hypertension in adolescence has become increasingly investigated. Hypertension in the context of overweight and obesity indicates a higher potential for cardiovascular disease (CVD) than is associated with either risk factor alone. Results from the Bogalusa Heart Study demonstrated that multiple risk factors in childhood have multiplicative rather than additive effects on the severity of coronary artery lesions. ${ }^{10}$ Overweight adolescents with hypertension have a higher likelihood of both elevated weight and BP persisting into adulthood. ${ }^{11,12}$ In addition, some complications of obesity are independently related to elevated $\mathrm{BP}$, such as obstructive sleep apnea. ${ }^{13}$ Because of their high-risk status, intervention in overweight adolescents with associated comorbidities, such as hypertension, should be considered. Fortunately, studies have demonstrated that those who reverse their obesity status prior to adulthood are less likely to be hypertensive in adulthood. ${ }^{14}$ Likewise those who resolve their elevated BP in youth have less risk of elevated BP and subclinical atherosclerosis in adulthood, with this reversal primarily linked to smaller gains in BMI in the time between adolescence and adulthood. ${ }^{15}$ This recognizes that adolescence is an opportune time for intervention and prevention of overweight- and obesityrelated hypertension. Despite the importance of this issue, there is little consensus worldwide as to how best to identify hypertension in overweight adolescents and the treatments that will result in the lowering of BP in this group.

\section{Overview of causes and incidence of hypertension in adolescence}

The most widely applied criteria for determining adolescent BP classification has been devised by the National High Blood Pressure Education Program (NHBPEP). ${ }^{16}$ This classification outlines that adolescents with a BP between the 90th and 95th age-, sex-, and height-determined percentiles are prehypertensive whilst those with a BP between the 95 th and 100th age-, sex-, and height-determined percentiles are hypertensive. This classification is applied to adolescents aged 17 years or younger, with BP status of adolescents aged 18-19 years determined using adult thresholds. ${ }^{17}$ Elevated SBP and/or diastolic BP (DBP) measured on at least three occasions is necessary to diagnose elevated BP (hypertension or prehypertension). Nevertheless, this criterion is rarely met in cross-sectional and longitudinal studies.

Hypertension can further be classified as essential, with no directly identifiable cause, or secondary due to detectable medical conditions. Essential hypertension is recognized significantly more in adolescence than in childhood, comprising approximately $85 \%-95 \%$ of diagnoses. ${ }^{9}$ Essential hypertension is largely asymptomatic and there are usually few findings on the physical examination, although high-risk signs, such as arteriovenous nipping of the retinal vessels, may be present in a minority. ${ }^{16}$ Whilst there is no single identifiable cause for essential hypertension in adolescence, there are a number of important risk factors. Although excess weight and adiposity are key, there are a number of other factors that affect the likelihood of developing hypertension in this age group. Adolescent hypertension has been linked to diets high in fat and sodium, sedentary behavior, insufficient physical activity, family history of hypertension or early CVD, and birth weight. ${ }^{16}$ The effects of ethnicity and sex have been less consistently demonstrated. It is possible these factors modify the strength of the relationship between BP and adiposity.

A recent publication from the National Health and Nutrition Examination Survey (NHANES) suggests the prevalence of prehypertension and hypertension in 8- to 17-year-olds is approximately one in ten. ${ }^{18}$ However, the exact worldwide prevalence of hypertension in adolescents is unclear and data regarding the extent of hypertension among this age group are not apparent given that many studies do not present age-stratified findings. In addition, it would be important to have BP classification based on normal-weight children. Otherwise, due to the strong association between BP and overweight/obesity, the inclusion of a high proportion of overweight/obese children would raise the threshold for normal BP. In a recent systematic review with metaanalysis, the prevalence issue was addressed by pooling BP data from 122,053 adolescents in 55 studies. They reported that the prevalence of elevated BP was $11.2 \%$ with higher rates found among males and those from low- and middleincome countries. ${ }^{19}$ Prehypertension appears to account for the largest proportion of the burden of elevated BP. In 2007, 
Din-Dzietham et $\mathrm{al}^{20}$ reported that in children and adolescents aged $8-17$ years, $10 \%$ were prehypertensive and $3.7 \%$ were hypertensive. An estimate in 2012 placed the prevalence of hypertension at $2.5 \%$ and prehypertension at $11.5 \%$, suggesting that the relative proportion of prehypertensive adolescents may be on the rise. ${ }^{21}$ Moreover, other recent studies have largely demonstrated that the overall prevalence of childhood and adolescent hypertension and prehypertension is increasing. Data from the NHANES has revealed that from 1988-1994 to 1999-2008 the odds of elevated BP increased by $27 \%$. $^{22}$ This upward trend is largely supported, ${ }^{23-26}$ though not completely. ${ }^{27,28}$ There is still large heterogeneity across studies reporting the prevalence of elevated BP in adolescence and this may be attributable to differences in study methodology. ${ }^{21}$ Overall, elevated BP in adolescence appears to be increasing and this rise can be explained at least in part by the increase in overweight and obesity.

\section{Review of evidence linking hypertension and overweight in adolescents}

There is a large amount of evidence linking hypertension and overweight in the adolescent population. Adolescents are overweight or obese according to the internationally accepted percentile charts based on an international multicenter survey. ${ }^{29}$ Overweight is defined as a BMI between the 85 th and 95 th age- and sex-specific percentiles, and obesity is defined as a BMI greater than the 95th age- and sex-specific percentile. Unlike BP, these percentile charts extend from 2 to 20 years and thus adult classifications are not necessary in later adolescence.

Several studies in adolescence have now investigated secular BP trends in relation to secular BMI trends. Overweight and obesity have been increasing rapidly over the last three decades and this parallels the rise in BP. Data from the US NHANES have revealed that $33.6 \%$ of adolescents aged 12-19 years were overweight or obese. ${ }^{2}$ Nevertheless, the trajectory of BP has not been as linear as the increases in BMI. Din-Dzietham et $\mathrm{al}^{20}$ revealed that between 1963 and 1988 , there was a downward trend in adolescent BP which is consistent with adult data over the same period..$^{30}$ Through this period, there was a relative plateau in population BMI levels. A steep increase in overweight and obesity was observed initially in the 1980s and there was a subsequent upswing in hypertension and prehypertension in adolescents. ${ }^{20,23}$ A subsequent publication reported that the proportion of overweight and obese adolescents (16-19 years) in an Israeli cohort increased from $13.2 \%$ to $21 \%$ between 1998 and $2011 .^{8}$ This is incongruous with recent data illustrating that in 8- to 17-yearolds, hypertension decreased marginally (from $3.0 \%$ to $1.6 \%$ ) while rate of prehypertension increased slightly (from $10.6 \%$ to $11.0 \%$ ) during a similar time frame. ${ }^{18}$ Nonetheless, the trajectory of BP appears to lag 10 years behind that of BMI and this may explain some of the variation in BP and BMI between these trends. These secular trends suggest that there is a relationship between excess weight and hypertension in adolescents. Further evidence in cross-sectional studies has been reviewed to evaluate this relationship. This relationship is particularly difficult to study in adolescence due to the paucity of studies exclusively in this age group.

Table 1 summarizes 13 studies that have examined the association between BMI and BP in adolescence using correlation coefficients. Studies were included in this table if they fulfilled the following requirements: 1) participants were aged between 10 and 19 years; 2) they reported correlation coefficients for association between BMI and BP; and 3) the publication was in English. A number of studies were identified which included results for adolescents and children combined and thus were excluded. Further, five studies presented their results stratified by sex and region and therefore there were a total of 21 data points for SBP and 20 data points for DBP. The age of participants ranged from 10 to 19 years and the mean age of subjects was 14.2 years. Sample sizes ranged from $n=24$ to $n=3,363$ participants. All studies included male and female participants, excepting one study of adolescent females from Brazil. ${ }^{31}$ Overall, this analysis revealed correlation coefficients between BMI and SBP ranging from $r=0.18$ to $r=0.48$ with a mean of 0.34 . Correlation coefficients between BMI and DBP ranged from $r=0.05$ to $r=0.36$ with a mean of 0.21 . This shows the tendency for SBP to have a higher association with BMI than DBP. This is consistent with reports that overweight adolescents are more likely to have isolated SBP or a rise in both BP components rather than an isolated elevation in DBP. ${ }^{32}$ Importantly, some studies have demonstrated that this association is only significant beyond a certain threshold of $\mathrm{BMI}^{33}$ and, therefore, associations may be stronger in the overweight and obese subpopulations during adolescence. ${ }^{34}$

The difference in the relationship between BMI and $\mathrm{BP}$ in adolescents was assessed on the basis of the relative proportion of overweight subjects and obese subjects in the cohort (Figure 1). Figure 1 illustrates that studies with higher proportions of obese or overweight adolescent participants tended to have higher correlation coefficients, although there was a great deal of inconsistency that may have resulted from the small number of studies $(\mathrm{N}=13)$ evaluated. 
Table I Summary of studies investigating the association between blood pressure and body mass index in adolescents

\begin{tabular}{|c|c|c|c|c|c|c|c|c|}
\hline Publication & Location & $\mathbf{N}$ & $\begin{array}{l}\text { Age range } \\
\text { (years) }\end{array}$ & $\begin{array}{l}\text { Sex } \\
\text { (\% male) }\end{array}$ & $\begin{array}{l}\text { Obese } \\
\text { (\%) }\end{array}$ & $\begin{array}{l}\text { Overweight } \\
\text { (\%) }\end{array}$ & SBP CC & DBP CC \\
\hline \multirow[t]{2}{*}{ Song et al ${ }^{135}$} & Korea & $\mathrm{I}, 757$ & $10-19$ & $100.0 \%$ & NA & $15.7 \%$ & $0.31 *$ & $0.11 *$ \\
\hline & & 1,606 & & $0.0 \%$ & NA & $20.8 \%$ & $0.20 *$ & 0.05 \\
\hline Abdul Razzak et al ${ }^{136}$ & Kuwait & 209 & $11-19$ & $61.2 \%$ & $100.0 \%$ & NA & $0.18 *$ & $0.16^{*}$ \\
\hline Duncan et $\mathrm{al}^{137}$ & Portugal & 445 & $10-17$ & $43.4 \%$ & $3.7 \%$ & $22.1 \%$ & $0.32 *$ & $0.23 *$ \\
\hline \multirow[t]{2}{*}{ Kim et al ${ }^{138}$} & Korea & 336 & $12-16$ & $100.0 \%$ & NA & NA & $0.47^{*}$ & $0.29 *$ \\
\hline & & 229 & & $0.0 \%$ & NA & NA & $0.48 *$ & $0.36 *$ \\
\hline \multirow[t]{2}{*}{ Mehdad et al ${ }^{139}$} & Morocco & 44 & $11-17$ & $100.0 \%$ & $13.6 \%$ & $47.7 \%$ & $0.42 *$ & 0.28 \\
\hline & & 123 & & $0.0 \%$ & $12.2 \%$ & $22.8 \%$ & $0.45^{*}$ & 0.34 \\
\hline Pecin et al ${ }^{140}$ & Croatia & 756 & $15-18$ & $49.6 \%$ & $3.5 \%$ & NA & $0.18^{*}$ & $0.20 *$ \\
\hline Rutkowski et al ${ }^{\mid 41}$ & Poland & 889 & $14-15$ & $51.9 \%$ & $8.0 \%$ & $8.0 \%$ & $0.36 *$ & $0.22 *$ \\
\hline \multirow[t]{2}{*}{ Ying-Xiu et al ${ }^{142}$} & China & 464 & 12 & $100.0 \%$ & $14.4 \%$ & $15.9 \%$ & $0.38^{*}$ & $0.28 *$ \\
\hline & & 456 & & $0.0 \%$ & $8.1 \%$ & $7.9 \%$ & $0.36 *$ & $0.23 *$ \\
\hline Pereira et $\mathrm{al}^{31}$ & Brazil & 113 & $14-19$ & $0.0 \%$ & NA & $31.0 \%$ & $0.34^{*}$ & $0.27^{*}$ \\
\hline Duncan et $\mathrm{al}^{143}$ & UK & 661 & $\mid 1-14$ & $58.1 \%$ & $7.4 \%$ & $21.8 \%$ & $0.37^{*}$ & $0.21 *$ \\
\hline Larsson et al ${ }^{144}$ & Sweden & 144 & 10 & $44.0 \%$ & $2.0 \%$ & $18.0 \%$ & $0.24 *$ & $0.17^{*}$ \\
\hline \multirow[t]{4}{*}{ Salvi et al ${ }^{145}$} & Algeria & 388 & $15-19$ & $100.0 \%$ & $1.0 \%$ & $4.6 \%$ & $0.33 *$ & $0.21 *$ \\
\hline & & 734 & & $0.0 \%$ & $1.7 \%$ & $8.4 \%$ & $0.23 *$ & $0.14 *$ \\
\hline & Italy & 407 & & $100.0 \%$ & $3.4 \%$ & $13.7 \%$ & $0.42 *$ & $0.23 *$ \\
\hline & & 528 & & $0.0 \%$ & $0.8 \%$ & $9.3 \%$ & $0.29 *$ & $0.12 *$ \\
\hline Guimarães et al ${ }^{146}$ & Brazil & 536 & $11-18$ & $41.0 \%$ & $23.5 \%$ & $36.9 \%$ & $0.44 *$ & NA \\
\hline Caprio et al ${ }^{147}$ & USA & 24 & $10-16$ & $0.0 \%$ & $58.3 \%$ & $\mathrm{NA}$ & 0.33 & -0.19 \\
\hline
\end{tabular}

Note: $* P<0.05$

Abbreviations: CC, correlation coefficient; DBP, diastolic blood pressure; NA, not available; SBP, systolic blood pressure.

Comparing the relative proportions of hypertension in overweight and non-overweight adolescents also provides useful information for risk prediction. Koebnick et $\mathrm{l}^{35}$ reported that the prevalence of hypertension in overweight adolescents $(2.1 \%)$ was twice that of normal-weight adolescents $(0.8 \%)$ aged 12-19 years. Further, prevalence of hypertension increased in a stepwise fashion according to magnitude of weight for all subgroups of age and sex. These findings are consistent with other studies showing that the odds of hypertension in overweight adolescents are significantly higher
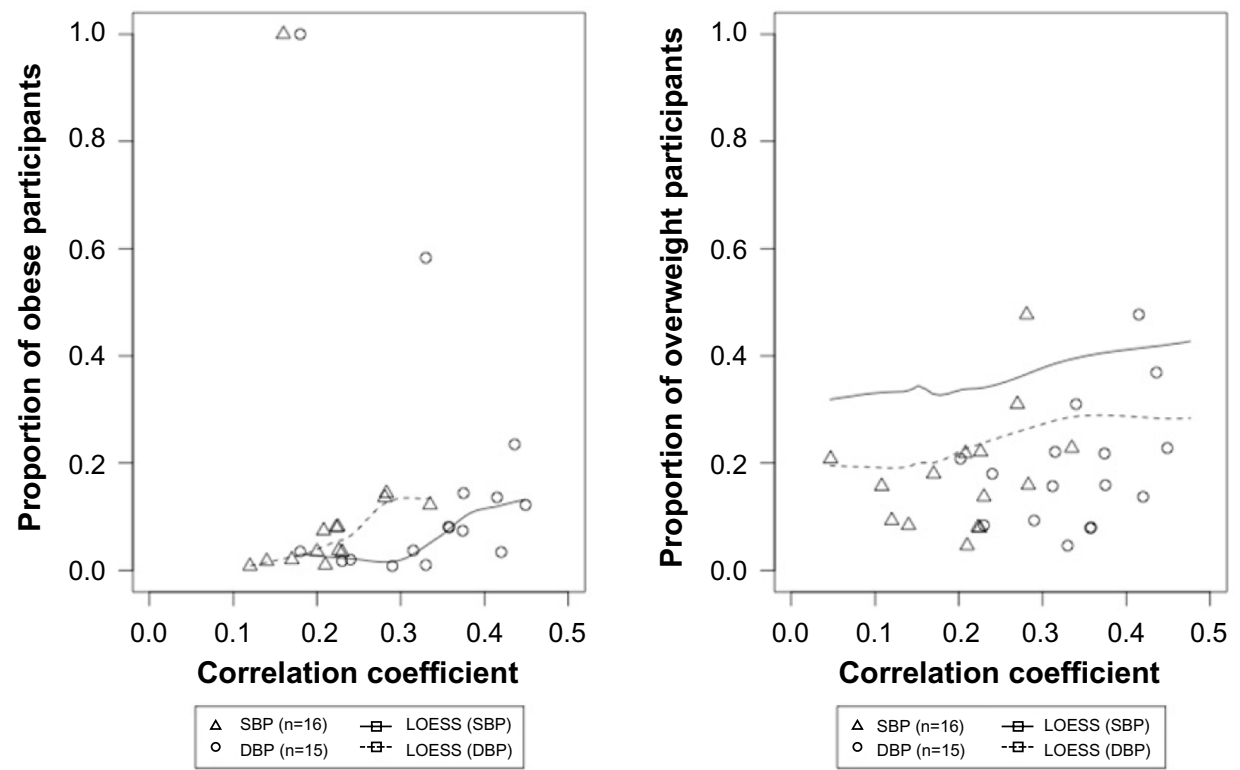

Figure I Scatterplot demonstrating the relationship between proportion of obese participants and proportion of overweight participants and the magnitude of SBP and DBP correlation coefficients.

Notes: LOESS creates smoothed curves for both SBP and DBP.There were 16 SBP data points and I5 DBP data points. Some data points are stratified according to sex or region.

Abbreviations: DBP, diastolic blood pressure; LOESS, locally-weighted scatterplot smoothing; SBP, systolic blood pressure. 
compared to normal-weight individuals and lower compared to obese individuals. ${ }^{36-40,138}$ It is clear that these prevalence rates reflect a dose-response relationship; however, the general classifications of overweight and obesity disregard the continuous positive association between BP and BMI levels. It is estimated that for each decile increase in BMI, SBP increases by $10 \mathrm{mmHg}$ and DBP increases by $3 \mathrm{mmHg} .{ }^{8}$ These are substantial differences that, if maintained into adulthood, would have a substantial impact on CVD risk.

Excess weight is evidently responsible for a large number of hypertension cases in adolescence. In a study of 7,746 adolescents aged $12-16$ years by Chiolero et al, ${ }^{41}$ the attributable fraction (AF) for combined overweight and obesity was highest among males aged $12-13$ years $(\mathrm{AF}=39 \%)$ and females aged $15-16$ years $(\mathrm{AF}=39 \%$ ). Comparatively, in children aged 5-6 years, increased BMI only accounted for 5\% and $9 \%$ of hypertension in girls and boys, respectively. Population AFs in adulthood are also lower and have been reported as $28 \%$ and $11 \%$ in two separate studies. ${ }^{42,43}$ Therefore, the proportion of hypertension explained by excess weight is greater during adolescence.

\section{Mechanisms of hypertension in overweight adolescents}

It is apparent that those adolescents who are overweight and obese have a higher likelihood of developing hypertension; however, the exact size of this effect is variable. This indicates that there may be additional factors influencing the likelihood of developing hypertension in overweight adolescents. The characteristics that distinguish overweight adolescents with hypertension from overweight adolescents who are normotensive are unclear. The cross-sectional data available in the overweight adolescent population is limited and thus factors in cohorts of overweight adolescents and children have also been investigated in this review. These nonmodifiable and modifiable factors have been examined and are summarized in Figure 2 and Table S1.

Figure 2 illustrates that there are factors that both attenuate and stimulate the development of hypertension in overweight adolescents. Despite clear evidence that male sex is a risk factor for the development of elevated BP in adolescence, the role of male sex in overweight adolescents is less certain and studies have provided conflicting results. ${ }^{44-46}$ Nevertheless, population data suggest that the overall likelihood of developing hypertension in adolescent males is higher. A large population cohort study demonstrated that sex did not modify the relationship between BMI and high BP. ${ }^{35}$ Stronger evidence exists for age affecting the development of hypertension in this group. A number of studies have reported that older adolescents have a greater $\mathrm{BP}$ response to alterations in $\mathrm{BMI}{ }^{35,36}$ This effect may be due to higher levels of hormones, such as estrogen, present

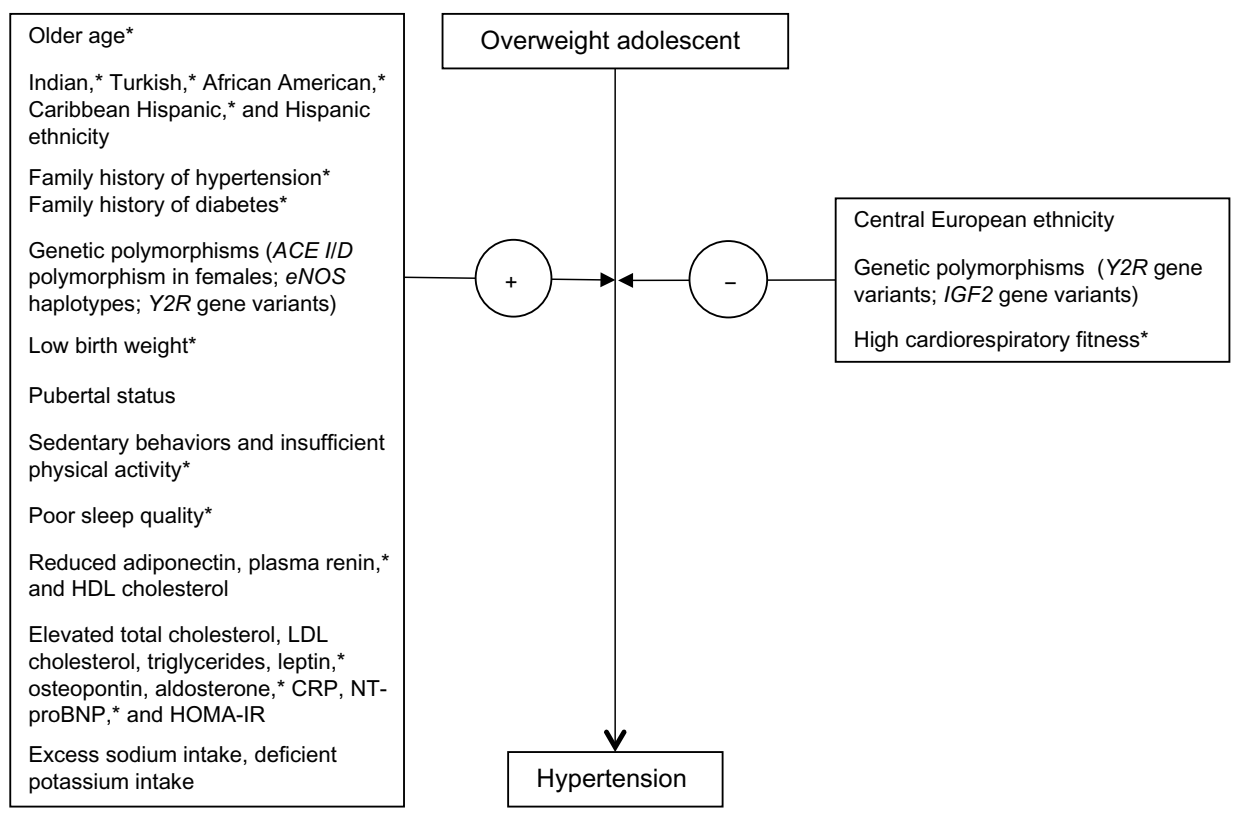

Figure 2 Factors associated with the development of hypertension in overweight adolescents.

Note: *Denotes studies that present effective estimates in adolescents only.

Abbreviations: ACE I/D, angiotensin converting enzyme insertion/deletion; CRP, C-reactive protein; eNOS, endothelial nitric oxide synthase; HDL, high-density lipoprotein; HOMAIR, homeostasis model assessment-estimated insulin resistance; IGF2, insulin-like growth factor; LDL, low-density lipoprotein; NT-proBNP, n-terminal pro-brain natriuretic peptide; $Y 2 R, Y 2$ receptor. 
during puberty. Siklar et $\mathrm{a}^{47}$ reported pubertal or postpubertal overweight adolescents are significantly more likely to develop elevations in BP compared to their prepubertal counterparts. However, this can only be a marginal stimulus for BP increases given that a large proportion of prepubertal individuals experience hypertensive change and subclinical changes initiating in childhood.

Ethnicity is another important factor in determining progression to hypertension in overweight adolescents who are Indian, African-American, Caribbean Hispanic, or Turkish. ${ }^{44,48-50}$ Harding et al ${ }^{48}$ noted that obese Indian adolescents were 8.43-times more likely to develop high SBP compared to obese white adolescents in the UK. The risk for hypertension was not significantly higher in nonobese Indian adolescents suggesting that the effect of ethnicity in this population is weight-dependent. A further study in the US has demonstrated that elevated BP was ten-times more common in obese minority youth (African American or Caribbean Hispanic). ${ }^{50}$ This may explain some of the differences observed in the genetic markers of those at highest risk for weight-related hypertension. A number of publications have looked at the influence of unique genetic polymorphisms, yet none have investigated this exclusively in adolescents. In such studies, endothelial nitric oxide synthase (eNOS), insulin-like growth factor (IGF2), and angiotensin converting enzyme insertion/deletion (ACE I/D) gene variants have been implicated in higher likelihood of hypertension whilst certain YR2 polymorphisms may be protective..$^{51,52}$ These genetic variants related primarily to the physiological mechanisms regulating BP such as enzymes ( $A C E I / D, e N O S)$, hormones (IGF2), and receptors $(Y 2 R)$. In a cohort of obese children and adolescents, Santoro et al demonstrated that those with the T585 allele of the Y2 receptor were less likely to develop hypertension than those with the CC and CT gene variants (odds ratio $=0.5$ ). ${ }^{53}$ Family history of hypertension or diabetes has also been shown to affect hypertensive status in obese adolescents ${ }^{45,47}$ although one report is conflicting. ${ }^{54}$ Further, low birth weight is also a strong predictor of hypertension in overweight adolescents. ${ }^{55,56}$

There are a number of potentially modifiable risk factors that are more likely to be present in those overweight adolescents with hypertension. Studies in overweight adolescents have revealed that high cardiorespiratory fitness may be protective for hypertension, ${ }^{57}$ yet very high levels of physical activity does not appear to have any effect. ${ }^{58}$ Marcelino et al ${ }^{57}$ showed that the protective effect of cardiorespiratory fitness arose only in those with high body fat but not necessarily high BMI. Conversely, low cardiorespiratory fitness increases the likelihood of hypertension in this group and those with both higher BMI and low maximal oxygen uptake were at highest risk of metabolic syndrome, which includes hypertension. Further, sedentary behaviors such as video game playing and television watching have been linked to an increased risk of developing hypertension in overweight adolescents. ${ }^{59,60}$ Interestingly, Goldfield et al ${ }^{59}$ observed that video game playing was the only behavior independently linked to elevated BP in overweight adolescents. Excess sodium intake and low potassium intake have been associated with elevated BMI and BP in adolescent cohorts. ${ }^{61-63}$ Yang et $\mathrm{al}^{163}$ reported that for every $100 \mathrm{mg}$ increase in daily dietary sodium of 8- to 18-year-olds, SBP increased by a standard deviation of 0.097 in all subjects and 0.141 in overweight or obese subjects. Of course, data from prospective cohort studies and randomized controlled trials can also be examined to determine if modifying these characteristics may be useful interventions, and this will be discussed further.

Overall, there are a number of characteristics that differentiate those overweight adolescents who are more likely to develop hypertension, but the biological mechanisms underlying these changes are uncertain. Several biochemical factors have been identified as elevated or reduced in those overweight adolescents who have hypertension as opposed to overweight adolescents who are normotensive (Figure 2 and Table S2). These subclinical markers may be implicated in the pathogenesis of hypertension or rather they may be a consequence of the disease itself. A number of hormones derived from adipose tissue have been linked to increased BP in overweight adolescents, including leptin, adiponectin, and osteopontin. A study in overweight adolescents revealed that SBP and DBP were inversely related to adiponectin levels independent of BMI. ${ }^{64}$ The regulatory role of hypoadiponectinemia has been confirmed in subsequent studies. ${ }^{65}$ Leptin has also been implicated as a mediator of the BP and weight relationship in adolescents. Tu et $\mathrm{al}^{66}$ reported concurrent rises in SBP, leptin, and heart rate, demonstrating that the effects of leptin on SBP may be occurring via sympathetic nervous system modulation and subsequent increased heart rate. Csabi et a ${ }^{67}$ also linked hyperinsulinemia to the development of hypertension in obese adolescents due to the activation of the sympathetic nervous system. In addition, there is also a trend toward higher levels of total cholesterol and low-density lipoprotein cholesterol and low high-density lipoprotein cholesterol in hypertensive and overweight adolescents that may represent a clustering of risk factors. ${ }^{47,68}$ Adult studies have extensively investigated the weight modulation of the renin-angiotensin system and 
both renin and aldosterone have shown to be elevated in hypertensive obese adolescents. ${ }^{69,70}$ Further, higher levels of CRP and NT-proBNP as well as microalbuminuria have been implicated. ${ }^{71,72}$

These factors provide an important insight into the possible mechanisms for the development of hypertension in overweight adolescents. The literature in adulthood is still unclear but implicates a number of factors. ${ }^{73}$ Although the evidence in adolescence is limited, the available data suggest similar processes to those in adulthood. The aforementioned risk factors and subclinical markers may ultimately prove useful in the stratification of those overweight adolescents with a higher likelihood of developing hypertension.

\section{Evaluation of current methods used in identifying low- and high-risk hypertension in overweight adolescents}

No universal guidelines or recommendations exist to define high-risk versus low-risk hypertension in overweight adolescents. However European, North American, and international guidelines clearly note the importance of evaluating for both complications and comorbidities associated with excess weight. These guidelines largely suggest screening all overweight and obese adolescents for hypertension. ${ }^{74-78,81,82}$ For example; US expert committee recommendations regarding adolescent overweight and obesity recommend an evaluation of BP in all those with a BMI above the 85 th percentile. ${ }^{83}$ Hansen et al ${ }^{84}$ indicated that prior identification of obesity status was associated with increased likelihood (odds ratio $=2.61$ ) of a correct hypertension diagnosis in those aged between 8 and 19 years. This suggests that pediatricians and family practitioners are aware that hypertension in an important complication in the overweight group of adolescents. Despite the appreciable evidence behind such guidelines, assessing overweight adolescents in clinical practice is problematic given that $33.6 \%$ of 12 - to 19 -year-olds are overweight. ${ }^{2}$ The individual and biochemical characteristics noted in the previous section may prove useful in distinguishing those overweight adolescents who would benefit most from early intervention.

Evaluation of BP in overweight adolescents should start with confirming the diagnosis of hypertension; however, there are a number of methodological issues that complicate the measurement of BP in this population. This is problematic due to the inherent variability of BP during childhood and adolescence and also the documented issues of BP misclassification in overweight subjects. ${ }^{85,86}$ Choosing an inappropriate cuff size is the most common source of methodological error in BP measurement of overweight or obese individuals and care should be taken to choose an appropriate cuff. ${ }^{87}$ In particular, small cuffs in overweight adolescents result in overestimation of BP and over-diagnoses of hypertension. ${ }^{88}$ Elevated BP must be detected on at least three separate occasions for a formal diagnosis. The results of a study of 1,020 adolescents showed that $20 \%$ had at least one measurement of elevated BP over the course of three visits although only $11.5 \%$ could be classified as having persistent prehypertension. ${ }^{21}$ In large cohort studies it is often not possible to fulfill this criteria and multiple measurements performed on a single occasion is standard practice. ${ }^{16,17}$ Although secondary hypertension is uncommon in adolescence, it is still necessary to exclude adverse and potentially treatable causes of hypertension, such as renal artery stenosis and pheochromocytoma. ${ }^{89}$ The likelihood of a secondary diagnosis is less in those already identified as being overweight or obese. Identification is further complicated by the use of a complex BP percentile system that uses critical values for each age, sex, and height percentile for those aged less than 18 years, which may impair the ability of physicians to immediately and accurately identify hypertension. ${ }^{84}$ Simplified alternatives to the NHBPEP definition have demonstrated similar predictive utility and may be useful given the increasing trend in adolescent weight-related hypertension. ${ }^{90-92}$

Although preventative management is ideal, a large proportion of those identified as overweight or obese have already developed hypertension and management is necessary. Such individuals can be further assessed as having high-risk or lowrisk hypertension. In this context it is useful to consider two different types of risk, concurrent and future risk. Concurrent risk relates to the likelihood of hypertensive target-organ damage in overweight adolescents whereas future risk describes the risk of persistent hypertension in adulthood or adult CVD. Those identified as having target-organ damage (eg, retinal changes or deterioration in renal function) can be considered as being high-risk for future complications based on this discovery alone. Those hypertensive and overweight adolescents at high risk may be an important subgroup to target more intensive interventions. The NHBPEP guidelines note that antihypertensive management should be targeted at lower thresholds ( $\leq 90$ th percentile) for those with concurrent comorbidities including overweight and obesity. ${ }^{16}$ There are some clear qualities relating to individual BP, adiposity, and demographics that increase the risk of current and future complications. 
There are a number of factors relating to BP which may be important in distinguishing risk of hypertensive disease in overweight adolescents. Magnitude of hypertension during adolescence appears to affect the risk of all-cause mortality. A longitudinal study of adolescent Swedish male conscripts showed that risk of all-cause mortality in adulthood increased proportionally with BP. ${ }^{93}$ Further, Hietalampi et $\mathrm{al}^{94}$ assessed 418 adolescents and noted that for every $1 \mathrm{mmHg}$ increase in SBP there was a $0.5 \mathrm{~g}$ increase in left ventricular mass. Consequently, the NHBPEP Working group recommends staging of hypertension in adolescents based on BP severity as this is often useful in determining treatment options and future risk. ${ }^{95}$ Regardless of BP magnitude, evidence of subclinical pathology should always be considered a marker of high-risk disease in overweight adolescents. ${ }^{96,97}$ Lubrano et al ${ }^{96}$ demonstrated that microalbuminuria was evident in those diagnosed as only prehypertensive. Individual components of BP may also confer risk and DBP has been established to be most predictive of future CVD risk in the adolescent population. Sundstrom et $\mathrm{al}^{93}$ showed that isolated DBP in male adolescents was more predictive of all-cause mortality in adulthood than isolated SBP. Despite this, it appears that the majority of overweight adolescents will have an isolated rise in SBP or a rise in both SBP and DBP; however, some studies are conflicting. ${ }^{98}$ Other research in adulthood describe that mean arterial pressure and pulse pressure are better predictors of future CVD and that this association is intensified if the adults are overweight or obese. ${ }^{99}$ This has not yet been demonstrated in normal-weight or overweight adolescents and further study is necessary to determine if these domains of BP would be useful in risk prediction. Ambulatory BP monitoring (ABPM) may be an alternate method to office BP measurement in distinguishing between high-risk and low-risk hypertension and serves to minimize BP variability and the incidence of white-coat hypertension. Several studies have concluded that the BP load, BP variability, and nighttime BP components of ABPM are superior predictors of left ventricular hypertrophy in overweight adolescents. ${ }^{86,95,100}$

Indicators of adiposity, other than BMI, have some utility in predicting additional risk in overweight hypertensive adolescents. Waist circumference, skin-fold thickness, and waist-height ratio have been investigated as isolated and combined measures of adiposity alongside BMI and revealed BMI to be a superior predictor of hypertensive disease overall. ${ }^{35,42}$ Although waist circumference, as a measure of both subcutaneous and visceral adiposity, may provide some additional benefit in detecting target-organ damage in overweight adolescents. ${ }^{101}$

A number of nonmodifiable characteristics are linked to high-risk hypertension independent of the extent of BMI or BP elevation. Age at diagnosis of hypertension represents higher-risk of persistence into adulthood. A systematic review revealed that those aged 15 years or older had the strongest tracking of BP from youth to adulthood with correlation coefficients of 0.43 for SBP and 0.31 for DBP. ${ }^{12}$ Ethnicity in overweight adolescents affects the likelihood of initially developing hypertension and certain ethnicities also confer a higher level of overall cardiovascular risk. Brady et al ${ }^{102}$ showed that non-white hypertensive overweight adolescents had higher likelihood of left ventricular hypertrophy compared to white individuals. Those with a triad of overweight, hypertension, and family history of hypertension in adolescence had poorer left ventricular function compared to paired or single combinations of these risk factors. ${ }^{103}$ Evaluation of the hypertensive and overweight adolescent may reveal other modifiable comorbidities, such as insulin resistance. Clustering of risk factors is common in this scenario and indicates a higher likelihood of target-organ damage. ${ }^{104,105}$

Evidently, factors such as elevated magnitude of BMI and BP, older age, family history of hypertension, and nonwhite ethnicity may indicate high-risk hypertension. This is useful in determining subgroups that may benefit more from specific management strategies, although the evidence is still tenuous and not widely integrated into clinical practice. Those with low-magnitude BP in the prehypertensive index should still be monitored as this is still estimated to progress to hypertension in a substantial proportion of individuals. Falkner et al ${ }^{106}$ reported that in the NHANES cohort, prehypertension progressed to hypertension at a rate of approximately $7 \%$ per year. Likewise those classed as overweight as opposed to obese represent a higher overall number of individuals likely to develop adverse outcomes in adulthood.

\section{Recommendations for management and prevention}

Treatment of hypertension in overweight adults has shown definite benefit for long-term morbidity and mortality related to CVD, with resolution of elevated BP prior to adulthood resulting in further risk reduction. The exact threshold at which overweight and hypertensive individuals would benefit most from intervention is unclear. It is possible that adolescence is the optimal period for preventing permanent cardiovascular damage, as it is early enough to reverse 
pathological changes but avoids issues of over-diagnoses experienced with screening in earlier childhood. As such, there is increasing interest in hypertension prevention and treatment strategies for overweight adolescents.

The cornerstone of hypertension management in overweight adolescents is weight reduction, in view of the strong association between adiposity and BP. Despite many studies investigating the management of excess weight in adolescence, few explore the results of such treatment on BP. The most recent US expert committee recommendations regarding the treatment of overweight adolescents cite only two papers relating to the management of hypertension. ${ }^{78-80}$ Nevertheless, a number of studies report BP as a secondary outcome. Dietary restriction of kilojoules and increased physical activity in isolation or combination has been compared in several randomized controlled trials. Results from the Special Turku Coronary Risk Factor Intervention Study revealed that a lowsaturated-fat diet resulted in BP decreases in adolescents, although it was unclear if this effect is different between normal and overweight participants. ${ }^{107,108}$ Aerobic exercise appears to be highly effective at decreasing BP. ${ }^{109-113}$ A review of physical activity interventions in obese adolescents demonstrated that approximately 40 minutes of aerobic type activities three to five times a week is necessary to reduce BP in this group. ${ }^{114}$ The size of BP reduction appears to be dependent on the intensity of aerobic exercise. A study of an aerobic exercise intervention in 43 obese adolescents showed that a high-intensity program results in greater BP decreases than a low-intensity program, although this difference in effect was only observed after 6 months. ${ }^{109,110}$ One preliminary study revealed that weight-training in combination with aerobic exercise resulted in lower SBP levels and assisted in maintaining lowered DBP in overweight adolescent subjects, although no studies have confirmed this effect. ${ }^{115}$ Overall, the literature shows combination regimes of diet and physical activity to be the most effective in reducing weight and BP in overweight adolescents although caloric restriction alone is still successful. ${ }^{116-118}$ Rocchini et al ${ }^{118}$ reported that SBP level and pathological vascular markers were lowered further when regular physical activity was added into a schedule of caloric restriction and counseling. The addition of psychological care is crucial and the interim report of the World Health Organization Commission on Ending Childhood Obesity emphasized the importance of a multidimensional approach to adolescent overweight. ${ }^{119}$ Dâmaso et $\mathrm{al}^{120}$ showed that a multidisciplinary approach involving nutrition, exercise, and behavioral therapy resulted in a $21 \%$ and $12 \%$ decrease in the prevalence of elevated SBP and DBP, respectively. Brownell et $\mathrm{al}^{79}$ also showed that maternal involvement in counseling sessions resulted in larger long-term reductions in BP.

Expert committee guidelines for the management of overweight in adolescents suggest that pharmacological therapy be reserved for individuals resistant to lifestyle and behavioral modification. ${ }^{78}$ Currently, the US Food and Drug Administration has only approved orlistat for the indication of pediatric obesity. ${ }^{121}$ A randomized controlled trial of 539 obese adolescents revealed that DBP significantly decreased in those treated with orlistat. ${ }^{122}$ Orlistat was not associated with a significant reduction in SBP in the same study. These findings were not consistent with one previous study, which demonstrated no change in BP. ${ }^{123}$ Metformin is another pharmacological agent that has proved useful in decreasing both BMI and BP in overweight adults. A systematic review has indicated that no strong evidence exists to suggest that metformin has a treatment effect on elevated BP levels in overweight adolescents. ${ }^{124}$ Bariatric surgery is not recommended for those adolescents in the overweight class. Nevertheless, it is important to note that studies have demonstrated the Roux-en-Y gastric bypass, laparoscopic adjustable gastric banding, and sleeve gastrectomy to be associated with appreciable reductions in BP postsurgery in adolescents. $^{125-127}$

A smaller proportion of strategies focus exclusively on targeting BP reductions. Studies looking at dietary interventions have largely focused on caloric restriction leading to weight reduction in adolescents; however, some macronutrients and micronutrients may have effects on BP independent of weight reduction. A trial of successive 2-week periods of high-sodium and low-sodium diet in obese and nonobese participants revealed that greater reductions in SBP and DBP were experienced by the obese group. ${ }^{128}$ Further, those who participated in a 20 -week weight-loss trial and lost at least $1 \mathrm{~kg}$ of weight experienced decreases in BP sodium sensitivity suggesting that adiposity modulates the relationship between $\mathrm{BP}$ and sodium. In contrast, milk proteins may be protective for BP increases in overweight adolescents. Arnberg et al ${ }^{129}$ demonstrated reductions of $1.8 \mathrm{mmHg}(2.7 \%)$ in DBP of overweight adolescents following a 12-week intervention with casein protein. These results are consistent with adult studies demonstrating a 3\% reduction in DBP following administration of casein. ${ }^{130}$ The effect on DBP is of particular interest given that DBP is known to be the strongest predictor of adult CVD in young adults. ${ }^{131}$ Guidelines for management of hypertension in children and adolescents further suggest that higher potassium, magnesium, and low-fat dairy may be useful; however, it is uncertain if these nutrients are of 
specific benefit in those with increased adiposity. Couch et al ${ }^{132}$ conducted a 3-month clinic-based trial of adolescents and demonstrated that adopting a "dietary approaches to stop hypertension" diet assisted in reducing baseline SBP and DBP. The dietary approaches to stop hypertension diet had relatively higher levels of fruit intake, potassium, magnesium, and low-fat dairy and lower levels of overall fat consumption compared to the hospital-based nutrition care (control) group.

Halbach et $\mathrm{al}^{133}$ outlined key indications for pharmacological treatment of hypertension in obese adolescents, including diabetes mellitus (type 1 and type 2), secondary hypertension, target-organ damage, and failure of nonpharmacologic therapy alone. This reflects treatment recommendations in the NHBPEP although no distinct set of advice is provided for those with concurrent overweight and hypertension in adolescence. ${ }^{16}$ ACE inhibitors, angiotensin-receptor blockers, beta-blockers, calcium channel blockers, and diuretics are agents that can be prescribed in adolescent hypertension. Those who are overweight or obese maybe benefit additionally from those with renal protective properties (ACE inhibitors or angiotensin-receptor blockers). ${ }^{7}$ As previously noted, uric acid has been implicated in the development of hypertension in overweight adolescents. Consequently, Soletsky and Feig ${ }^{134}$ studied the effect of uric acid reduction using pharmacological agents (xanthine oxidase inhibitor, allopurinol, uricosuric drugs, or probenecid) in obese adolescents aged 11-17 years for 7 weeks. Those provided with urate-lowering therapy experienced significant reductions in SBP (10.2 $\mathrm{mmHg})$ and DBP $(9.0 \mathrm{mmHg})$ whilst those in the placebo group experienced only minor increases in BP.

Overall, management of hypertension in overweight adolescents should primarily involve lifestyle modification; however, a lower threshold for pharmaceutical intervention might be considered. Prevention of hypertension in overweight adolescents focuses on the behavioral therapies outlined above although no targeted long-term follow-up trials were identified. Lastly, trials with prolonged follow-up periods should be considered given that the reversal of vascular dysfunction is apparent only over a longer period of time.

\section{Conclusion}

The incidence of hypertension in adolescence appears to be increasing alongside the epidemic of adolescent obesity. As a result, obesity has been widely implicated in the pathogenesis of adolescent hypertension although, as in adulthood, the mechanisms still remain unclear. Overweight adolescents with a family history of hypertension, low birth weight, nonwhite ethnicity, sedentary behavior or insufficient physical activity, and poor sleep quality have a higher likelihood of developing hypertension. Evidence also suggests high cardiorespiratory fitness and certain genetic polymorphisms may be protective in this setting. Further studies investigating biochemical markers in hypertensive overweight adolescents have found variations in the levels of hormones and enzymes involved in the renin-angiotensin system, lipid metabolism, and inflammation. Adolescents who develop hypertension may be considered high-risk for concurrent target hypertensive organ damage and future CVD risk based on several factors, including BP magnitude, BMI magnitude, age, family history, and ethnicity. Overall, the majority of studies reviewed pertained to obese adolescents and literature specific to the overweight subgroup is limited. Continued research is necessary to determine the value of treatment and screening in hypertensive overweight adolescents. Lifestyle modification and pharmacotherapies have been demonstrated to be successful in preventing hypertension and reducing already elevated BP in this group.

\section{Disclosure}

The authors report no conflicts of interest in this work.

\section{References}

1. World Health Organization. Interim Report of the Commission on Ending Childhood Obesity. Geneva: WHO; 2015 [cited April 1, 2015]; Available from: http://www.who.int/end-childhood-obesity/commission-endingchildhood-obesity-interim-report.pdf?ua=1. Accessed April 1, 2015.

2. Ogden CL, Carroll MD, Kit BK, Flegal KM. Prevalence of obesity and trends in body mass index among US children and adolescents, 1999-2010. JAMA. 2012;307(5):483-490.

3. Reilly JJ, Kelly J. Long-term impact of overweight and obesity in childhood and adolescence on morbidity and premature mortality in adulthood: systematic review. Int J Obes (Lond). 2011;35(7):891-898.

4. Adolescent development [webpage on the Internet]. Geneva: WHO; 2015 [cited February 1, 2015]; Available from: http://www.who.int/ maternal_child_adolescent/topics/adolescence/dev/en/. Accessed February 1, 2015.

5. Friedemann C, Heneghan C, Mahtani K, Thompson M, Perera R, Ward AM. Cardiovascular disease risk in healthy children and its association with body mass index: systematic review and meta-analysis. $B M J$. 2012;345:e4759.

6. World Health Organization. Global Health Risks: Mortality and Burden of Disease Attributable to Selected Major Risks. Geneva: WHO; 2009 [cited April 1, 2015]; Available from: http://www.who.int/healthinfo/ global_burden_disease/GlobalHealthRisks_report_full.pdf. Accessed April 1, 2015.

7. Flynn JT, Falkner BE. Obesity hypertension in adolescents: epidemiology, evaluation, and management. J Clin Hypertens (Greenwich). 2011; 13(5):323-331.

8. Chorin E, Hassidim A, Hartal M, et al. Trends in Adolescents Obesity and the Association between BMI and Blood Pressure: A Cross-Sectional Study in 714,922 Healthy Teenagers. Am J Hypertens. 2015;28(9):1157-1163.

9. Flynn JT. Evaluation and management of hypertension in childhood. Prog Pediatr Cardiol. 2001;12(2):177-188. 
10. Berenson GS, Srinivasan SR, Bao W, Newman WP 3rd, Tracy RE, Wattigney WA. Association between multiple cardiovascular risk factors and atherosclerosis in children and young adults. The Bogalusa Heart Study. N Engl J Med. 1998;338(23):1650-1656.

11. Singh AS, Mulder C, Twisk JW, van Mechelen W, Chinapaw MJ. Tracking of childhood overweight into adulthood: a systematic review of the literature. Obes Rev. 2008;9(5):474-488.

12. Chen X, Wang Y. Tracking of blood pressure from childhood to adulthood: a systematic review and meta-regression analysis. Circulation. 2008;117(25):3171-3180.

13. Horne RS, Yang JS, Walter LM, et al. Elevated blood pressure during sleep and wake in children with sleep-disordered breathing. Pediatrics. 2011;128(1):e85-e92.

14. Juonala M, Magnussen CG, Berenson GS, et al. Childhood adiposity, adult adiposity, and cardiovascular risk factors. $N \mathrm{Engl} \mathrm{J} \mathrm{Med}$. 2011;365(20):1876-1885.

15. Juhola J, Magnussen CG, Berenson GS, et al. Combined effects of child and adult elevated blood pressure on subclinical atherosclerosis: the International Childhood Cardiovascular Cohort Consortium. Circulation. 2013;128(3):217-224.

16. National High Blood Pressure Education Program Working Group on High Blood Pressure in Children and Adolescents. The fourth report on the diagnosis, evaluation, and treatment of high blood pressure in children and adolescents. Pediatrics. 2004;114(2 Suppl 4th Report):555-576.

17. James PA, Oparil S, Carter BL, et al. 2014 evidence-based guideline for the management of high blood pressure in adults: report from the panel members appointed to the Eighth Joint National Committee (JNC 8). JAMA. 2014;311(5):507-520.

18. Kit BK, Kuklina E, Carroll MD, Ostchega Y, Freedman DS, Ogden CL. Prevalence of and trends in dyslipidemia and blood pressure among US children and adolescents, 1999-2012. JAMA Pediatr. 2015;169(3): 272-279.

19. de Moraes AC, Lacerda MB, Moreno LA, Horta BL, Carvalho HB. Prevalence of high blood pressure in 122,053 adolescents: a systematic review and meta-regression. Medicine (Baltimore). 2014; 93(27):e232.

20. Din-Dzietham R, Liu Y, Bielo MV, Shamsa F. High blood pressure trends in children and adolescents in national surveys, 1963 to 2002. Circulation. 2007;116(13):1488-1496.

21. Acosta AA, Samuels JA, Portman RJ, Redwine KM. Prevalence of persistent prehypertension in adolescents. J Pediatr. 2012;160(5):757-761.

22. Rosner B, Cook NR, Daniels S, Falkner B. Childhood blood pressure trends and risk factors for high blood pressure: the NHANES experience 1988-2008. Hypertension. 2013;62(2):247-254.

23. Muntner P, He J, Cutler JA, Wildman RP, Whelton PK. Trends in blood pressure among children and adolescents. JAMA. 2004;291(17):2107-2113.

24. Peters H, Whincup PH, Cook DG, Law C, Li L. Trends in blood pressure in 9 to 11-year-old children in the United Kingdom 1980-2008: the impact of obesity. J Hypertens. 2012;30(9):1708-1717.

25. Kollias A, Pantsiotou K, Karpettas N, Roussias L, Stergiou GS. Tracking of blood pressure from childhood to adolescence in a Greek cohort. Eur J Public Health. 2012;22(3):389-393.

26. Liang YJ, Xi B, Hu YH, et al. Trends in blood pressure and hypertension among Chinese children and adolescents: China Health and Nutrition Surveys 1991-2004. Blood Press. 2011;20(1):45-53.

27. Freedman DS, Goodman A, Contreras OA, DasMahapatra P, Srinivasan SR, Berenson GS. Secular trends in BMI and blood pressure among children and adolescents: the Bogalusa Heart Study. Pediatrics. 2012;130(1):e159-e166.

28. Chiolero A, Paradis G, Madeleine G, Hanley JA, Paccaud F, Bovet P. Discordant secular trends in elevated blood pressure and obesity in children and adolescents in a rapidly developing country. Circulation. 2009;119(4):558-565.

29. Cole TJ, Bellizzi MC, Flegal KM, Dietz WH. Establishing a standard definition for child overweight and obesity worldwide: international survey. BMJ. 2000;320(7244):1240-1243.
30. Burt VL, Cutler JA, Higgins M, et al. Trends in the prevalence, awareness, treatment, and control of hypertension in the adult US population. Data from the health examination surveys, 1960 to 1991. Hypertension. 1995;26(1):60-69.

31. Pereira PF, Serrano HM, Carvalho GQ, et al. Body fat location and cardiovascular disease risk factors in overweight female adolescents and eutrophic female adolescents with a high percentage of body fat. Cardiol Young. 2012;22(2):162-169.

32. Sorof JM, Poffenbarger T, Franco K, Bernard L, Portman RJ. Isolated systolic hypertension, obesity, and hyperkinetic hemodynamic states in children. J Pediatr. 2002;140(6):660-666.

33. Cassano PA, Segal MR, Vokonas PS, Weiss ST. Body fat distribution, blood pressure, and hypertension. A prospective cohort study of men in the normative aging study. Ann Epidemiol. 1990;1(1): 33-48.

34. Dyer AR, Elliott P. The INTERSALT study: relations of body mass index to blood pressure. INTERSALT Co-operative Research Group. J Hum Hypertens. 1989;3(5):299-308.

35. Koebnick C, Black MH, Wu J, et al. High blood pressure in overweight and obese youth: implications for screening. J Clin Hypertens (Greenwich). 2013;15(11):793-805.

36. Chiolero A, Cachat F, Burnier M, Paccaud F, Bovet P. Prevalence of hypertension in schoolchildren based on repeated measurements and association with overweight. J Hypertens. 2007;25(11):2209-2217.

37. McNiece KL, Poffenbarger TS, Turner JL, Franco KD, Sorof JM, Portman RJ. Prevalence of hypertension and pre-hypertension among adolescents. J Pediatr. 2007;150(6):640-644, 644. e1.

38. Lin FH, Chu NF, Hsieh AT. The trend of hypertension and its relationship to the weight status among Taiwanese young adolescents. J Hum Hypertens. 2012;26(1):48-55.

39. Stray-Pedersen M, Helsing RM, Gibbons L, et al. Weight status and hypertension among adolescent girls in Argentina and Norway: data from the ENNyS and HUNT studies. BMC Public Health. 2009;9:398.

40. Sorof JM, Lai D, Turner J, Poffenbarger T, Portman RJ. Overweight, ethnicity, and the prevalence of hypertension in school-aged children. Pediatrics. 2004;113(3 Pt 1):475-482.

41. Chiolero A, Madeleine G, Gabriel A, Burnier M, Paccaud F, Bovet P. Prevalence of elevated blood pressure and association with overweight in children of a rapidly developing country. J Hum Hypertens. 2007; 21(2):120-127.

42. Geleijnse JM, Kok FJ, Grobbee DE. Impact of dietary and lifestyle factors on the prevalence of hypertension in Western populations. Eur J Public Health. 2004;14(3):235-239.

43. Wilson PW, D'Agostino RB, Sullivan L, Parise H, Kannel WB. Overweight and obesity as determinants of cardiovascular risk: the Framingham experience. Arch Intern Med. 2002;162(16):1867-1872.

44. Hannon TS, Gupta S, Li Z, et al. The effect of body mass index on blood pressure varies by race among obese children. J Pediatr Endocrinol Metab. 2015;28(5-6):533-538.

45. La Manna A, Spagnoletti T, Galizia G, Ponticiello L, De Luca R. [Statistical analysis of risk factors for hypertension in obese children]. Boll Soc Ital Biol Sper. 1982;58(5):253-258. Italian.

46. Koenigsberg J, Boyd GS, Gidding SS, Hassink SG, Falkner B. Association of age and sex with cardiovascular risk factors and insulin sensitivity in overweight children and adolescents. J Cardiometab Syndr. 2006;1(4):253-258.

47. Siklar Z, Berberoglu M, Savas Erdeve S, et al. Contribution of clinical, metabolic, and genetic factors on hypertension in obese children and adolescents. J Pediatr Endocrinol Metab. 2011;24(1-2):21-24.

48. Harding S, Maynard MJ, Cruickshank K, Teyhan A. Overweight, obesity and high blood pressure in an ethnically diverse sample of adolescents in Britain: the Medical Research Council DASH study. Int J Obes (Lond). 2008;32(1):82-90.

49. Martin L, Oepen J, Reinehr T, et al. Ethnicity and cardiovascular risk factors: evaluation of 40,921 normal-weight, overweight or obese children and adolescents living in Central Europe. Int J Obes (Lond). 2015;39(1):45-51. 
50. Puri M, Flynn JT, Garcia M, Nussbaum H, Freeman K, DiMartino-Nardi JR. The frequency of elevated blood pressure in obese minority youth. J Clin Hypertens (Greenwich). 2008;10(2):119-124.

51. Faienza MF, Santoro N, Lauciello R, et al. IGF2 gene variants and risk of hypertension in obese children and adolescents. Pediatr Res. 2010;67(4):340-344.

52. Souza-Costa DC, Belo VA, Silva PS, et al. eNOS haplotype associated with hypertension in obese children and adolescents. Int J Obes (Lond). 2011;35(3):387-392.

53. Santoro N, Del Giudice EM, Grandone A, et al. Y2 receptor gene variants reduce the risk of hypertension in obese children and adolescents. J Hypertens. 2008;26(8):1590-1594.

54. Nishina M, Kikuchi T, Yamazaki H, Kameda K, Hiura M, Uchiyama M. Relationship among systolic blood pressure, serum insulin and leptin, and visceral fat accumulation in obese children. Hypertens Res. 2003;26(4):281-288.

55. Lurbe E, Carvajal E, Torro I, Aguilar F, Alvarez J, Redon J. Influence of concurrent obesity and low birth weight on blood pressure phenotype in youth. Hypertension. 2009;53(6):912-917.

56. Strufaldi MW, Silva EM, Franco MC, Puccini RF. Blood pressure levels in childhood: probing the relative importance of birth weight and current size. Eur J Pediatr. 2009;168(5):619-624.

57. Marcelino G, Melich-Cerveira J, Paccaud F, Marques-Vidal P. Obese and fit adolescents have lower blood pressure levels than obese and unfit counterparts. J Sports Med Phys Fitness. 2012;52(6):639-646.

58. Hayes HM, Eisenmann JC, Pfeiffer K, Carlson JJ. Weight status, physical activity, and vascular health in 9- to 12-year-old children. $J$ Phys Act Health. 2013;10(2):205-210.

59. Goldfield GS, Kenny GP, Hadjiyannakis S, et al. Video game playing is independently associated with blood pressure and lipids in overweight and obese adolescents. PLoS One. 2011;6(11):e26643.

60. Pardee PE, Norman GJ, Lustig RH, Preud'homme D, Schwimmer JB. Television viewing and hypertension in obese children. Am J Prev Med. 2007;33(6):439-443.

61. Stabouli S, Papakatsika S, Kotsis V. The role of obesity, salt and exercise on blood pressure in children and adolescents. Expert Rev Cardiovasc Ther. 2011;9(6):753-761.

62. Campanozzi A, Avallone S, Barbato A, et al. High sodium and low potassium intake among Italian children: relationship with age, body mass and blood pressure. PLoS One. 2015;10(4):e0121183.

63. Yang Q, Zhang Z, Kuklina EV, et al. Sodium intake and blood pressure among US children and adolescents. Pediatrics. 2012;130(4): 611-619.

64. Shatat IF, Freeman KD, Vuguin PM, Dimartino-Nardi JR, Flynn JT. Relationship between adiponectin and ambulatory blood pressure in obese adolescents. Pediatr Res. 2009;65(6):691-695.

65. Lezhenko G, Gladun E. [The role of osteopontin and adiponectin in the development of insulin resistance and hypertension in obesed adolescents]. Georgian Med News. 2013;(214):43-48. Russian.

66. Tu W, Eckert GJ, DiMeglio LA, Yu Z, Jung J, Pratt JH. Intensified effect of adiposity on blood pressure in overweight and obese children. Hypertension. 2011;58(5):818-824.

67. Csabi G, Molnár D, Hartmann G. Urinary sodium excretion: association with hyperinsulinaemia, hypertension and sympathetic nervous system activity in obese and control children. Eur J Pediatr. 1996;155(10): 895-897.

68. Glowinska B, Urban M, Koput A. Cardiovascular risk factors in children with obesity, hypertension and diabetes: lipoprotein(a) levels and body mass index correlate with family history of cardiovascular disease. Eur J Pediatr. 2002;161(10):511-518.

69. Shatat IF, Flynn JT. Relationships between renin, aldosterone, and 24-hour ambulatory blood pressure in obese adolescents. Pediatr Res. 2011;69(4):336-340.

70. Rocchini AP, Katch VL, Grekin R, Moorehead C, Anderson J. Role for aldosterone in blood pressure regulation of obese adolescents. Am J Cardiol. 1986;57(8):613-618.
71. Pervanidou P, Akalestos A, Sakka S, Kanaka-Gantenbein C, Papassotiriou I, Chrousos GP. Gender dimorphic associations between $\mathrm{N}$-terminal pro-brain natriuretic peptide, body mass index and blood pressure in children and adolescents. Horm Res Paediatr. 2010;73(5): 341-348.

72. Noronha JA, Medeiros CC, Cardoso Ada S, Gonzaga NC, Ramos AT, Ramos AL. C-reactive protein and its relation to high blood pressure in overweight or obese children and adolescents. Rev Paul Pediatr. 2013; 31(3):z331-z337.

73. Landsberg L, Aronne LJ, Beilin LJ, et al. Obesity-related hypertension: pathogenesis, cardiovascular risk, and treatment: a position paper of The Obesity Society and the American Society of Hypertension. J Clin Hypertens (Greenwich). 2013;15(1):14-33.

74. August GP, Caprio S, Fennoy I, et al. Prevention and treatment of pediatric obesity: an endocrine society clinical practice guideline based on expert opinion. J Clin Endocrinol Metab. 2008;93(12): 4576-4599.

75. National Clinical Guideline Centre (UK). Obesity: Identification, Assessment and Management of Overweight and Obesity in Children, Young People and Adults: Partial Update of CG43. London: National Institute for Health and Care Excellence (UK); 2014.

76. Speiser PW, Rudolf MC, Anhalt H, et al. Childhood obesity. J Clin Endocrinol Metab. 2005;90(3):1871-1887.

77. Lau DC; Obesity Canada Clinical Practice Guidelines Steering Committee and Expert Panel. Synopsis of the 2006 Canadian clinical practice guidelines on the management and prevention of obesity in adults and children. CMAJ. 2007;176(8):1103-1106.

78. Spear BA, Barlow SE, Ervin C, et al. Recommendations for treatment of child and adolescent overweight and obesity. Pediatrics. 2007; 120 Suppl 4:S254-S288.

79. Brownell KD, Kelman JH, Stunkard AJ. Treatment of obese children with and without their mothers: changes in weight and blood pressure. Pediatrics. 1983;71(4):515-523.

80. McMurray RG, Harrell JS, Bangdiwala SI, Bradley CB, Deng S, Levine A. A school-based intervention can reduce body fat and blood pressure in young adolescents. J Adolesc Health. 2002;31(2):125-132.

81. Estrada E, Eneli I, Hampl S, et al. Children's Hospital Association consensus statements for comorbidities of childhood obesity. Child Obes. 2014;10(4):304-317.

82. Baker JL, Farpour-Lambert NJ, Nowicka P, Pietrobelli A, Weiss R; Childhood Obesity Task Force of the European Association for the Study of Obesity. Evaluation of the overweight/obese child - practical tips for the primary health care provider: recommendations from the Childhood Obesity Task Force of the European Association for the Study of Obesity. Obes Facts. 2010;3(2):131-137.

83. Barlow SE; Expert Committee. Expert committee recommendations regarding the prevention, assessment, and treatment of child and adolescent overweight and obesity: summary report. Pediatrics. 2007; 120 Suppl 4:S164-S192.

84. Hansen ML, Gunn PW, Kaelber DC. Underdiagnosis of hypertension in children and adolescents. JAMA. 2007;298(8):874-879.

85. Falkner B. Hypertension in children and adolescents: epidemiology and natural history. Pediatr Nephrol. 2010;25(7):1219-1224.

86. Sorof J, Daniels S. Obesity hypertension in children: a problem of epidemic proportions. Hypertension. 2002;40(4):441-447.

87. Donahue RP, Prineas RJ, Gomez O, Hong CP. Tracking of elevated systolic blood pressure among lean and overweight adolescents: the Minneapolis Children's Blood Pressure Study. J Hypertens. 1994;12(3):303-308.

88. Ostchega Y, Prineas RJ, Paulose-Ram R, Grim CM, Willard G, Collins D. National Health and Nutrition Examination Survey 1999-2000: effect of observer training and protocol standardization on reducing blood pressure measurement error. J Clin Epidemiol. 2003;56(8):768-774.

89. Flynn JT, Alderman MH. Characteristics of children with primary hypertension seen at a referral center. Pediatr Nephrol. 2005;20(7): 961-966. 
90. Aatola H, Magnussen CG, Koivistoinen T, et al. Simplified definitions of elevated pediatric blood pressure and high adult arterial stiffness. Pediatrics. 2013;132(1):e70-e76.

91. Kaelber DC, Pickett F. Simple table to identify children and adolescents needing further evaluation of blood pressure. Pediatrics. 2009; 123(6):e972-e974.

92. Mitchell CK, Theriot JA, Sayat JG, Muchant DG, Franco SM. A simplified table improves the recognition of paediatric hypertension. J Paediatr Child Health. 2011;47(1-2):22-26.

93. Sundström J, Neovius M, Tynelius P, Rasmussen F. Association of blood pressure in late adolescence with subsequent mortality: cohort study of Swedish male conscripts. BMJ. 2011;342:d643.

94. Hietalampi H, Pahkala K, Jokinen E, et al. Left ventricular mass and geometry in adolescence: early childhood determinants. Hypertension. 2012;60(5):1266-1272.

95. McNiece KL, Gupta-Malhotra M, Samuels J, et al. Left ventricular hypertrophy in hypertensive adolescents: analysis of risk by 2004 National High Blood Pressure Education Program Working Group staging criteria. Hypertension. 2007;50(2):392-395.

96. Lubrano R, Travasso E, Raggi C, Guido G, Masciangelo R, Elli M. Blood pressure load, proteinuria and renal function in pre-hypertensive children. Pediatr Nephrol. 2009;24(4):823-831.

97. Murgan I, Beyer S, Kotliar KE, et al. Arterial and retinal vascular changes in hypertensive and prehypertensive adolescents. $\mathrm{Am} \mathrm{J}$ Hypertens. 2013;26(3):400-408.

98. Chirinos JA, Franklin SS, Townsend RR, Raij L. Body mass index and hypertension hemodynamic subtypes in the adult US population. Arch Intern Med. 2009;169(6):580-586.

99. Franklin SS. The importance of diastolic blood pressure in predicting cardiovascular risk. J Am Soc Hypertens. 2007;1(1):82-93.

100. Belsha CW, Wells TG, McNiece KL, Seib PM, Plummer JK, Berry PL. Influence of diurnal blood pressure variations on target organ abnormalities in adolescents with mild essential hypertension. Am J Hypertens. 1998;11(4 Pt 1):410-417.

101. Litwin M, Niemirska A, Sladowska-Kozlowska J, et al. Regression of target organ damage in children and adolescents with primary hypertension. Pediatr Nephrol. 2010;25(12):2489-2499.

102. Brady TM, Fivush B, Flynn JT, Parekh R. Ability of blood pressure to predict left ventricular hypertrophy in children with primary hypertension. J Pediatr. 2008;152(1):73-78, 78. e1.

103. Baszun-Stepaniuk E, Urban M, Głowińska B. [Left ventricular mass and function in hypertensive and obese children and adolescents with family history of cardiovascular diseases]. Pol Merkur Lekarski. 2004;16(95):420-424. Polish.

104. l'Allemand-Jander D. Clinical diagnosis of metabolic and cardiovascular risks in overweight children: early development of chronic diseases in the obese child. Int J Obes (Lond). 2010;34 Suppl 2: S32-S36.

105. Katzmarzyk PT, Srinivasan SR, Chen W, Malina RM, Bouchard C, Berenson GS. Body mass index, waist circumference, and clustering of cardiovascular disease risk factors in a biracial sample of children and adolescents. Pediatrics. 2004;114(2):e198-e205.

106. Falkner B, Gidding SS, Portman R, Rosner B. Blood pressure variability and classification of prehypertension and hypertension in adolescence. Pediatrics. 2008;122(2):238-242.

107. Hakanen M, Lagström H, Pahkala K, et al. Dietary and lifestyle counselling reduces the clustering of overweight-related cardiometabolic risk factors in adolescents. Acta Paediatr. 2010;99(6):888-895.

108. Niinikoski H, Jula A, Viikari J, et al. Blood pressure is lower in children and adolescents with a low-saturated-fat diet since infancy: the special turku coronary risk factor intervention project. Hypertension. 2009;53(6):918-924.

109. Farah BQ, Ritti-Dias RM, Balagopal PB, Hill JO, Prado WL. Does exercise intensity affect blood pressure and heart rate in obese adolescents? A 6-month multidisciplinary randomized intervention study. Pediatr Obes. 2014;9(2):111-120.
110. Silva HJ, Andersen LB, Lofrano-Prado MC, et al. Improvements on Cardiovascular Diseases Risk Factors in Obese Adolescents: A Randomized Exercise Intervention Study. J Phys Act Health. 2015;12(4): $553-560$

111. Gutin B, Barbeau P, Owens S, et al. Effects of exercise intensity on cardiovascular fitness, total body composition, and visceral adiposity of obese adolescents. Am J Clin Nutr. 2002;75(5):818-826.

112. Meyer AA, Kundt G, Lenschow U, Schuff-Werner P, Kienast W. Improvement of early vascular changes and cardiovascular risk factors in obese children after a six-month exercise program. J Am Coll Cardiol. 2006;48(9):1865-1870.

113. Tjønna AE1, Stølen TO, Bye A, et al. Aerobic interval training reduces cardiovascular risk factors more than a multitreatment approach in overweight adolescents. Clin Sci (Lond). 2009;116(4):317-326.

114. Torrance B, McGuire KA, Lewanczuk R, McGavock J. Overweight, physical activity and high blood pressure in children: a review of the literature. Vasc Health Risk Manag. 2007;3(1):139-149.

115. Hagberg JM, Ehsani AA, Goldring D, Hernandez A, Sinacore DR, Holloszy JO. Effect of weight training on blood pressure and hemodynamics in hypertensive adolescents. J Pediatr. 1984;104(1): 147-151.

116. Becque MD, Katch VL, Rocchini AP, Marks CR, Moorehead C. Coronary risk incidence of obese adolescents: reduction by exercise plus diet intervention. Pediatrics. 1988;81(5):605-612.

117. Ribeiro MM, Silva AG, Santos NS, et al. Diet and exercise training restore blood pressure and vasodilatory responses during physiological maneuvers in obese children. Circulation. 2005;111(15):1915-1923.

118. Rocchini AP, Katch V, Anderson J, et al. Blood pressure in obese adolescents: effect of weight loss. Pediatrics. 1988;82(1):16-23

119. Gluckman P, Nishtar S, Armstrong T. Ending childhood obesity: a multidimensional challenge. Lancet. 2015;385(9973):1048-1050.

120. Dâmaso AR, de Piano A, Campos RM, et al. Multidisciplinary approach to the treatment of obese adolescents: effects on cardiovascular risk factors, inflammatory profile, and neuroendocrine regulation of energy balance. Int J Endocrinol. 2013;2013:541032.

121. Mathis L. Orlistat Update: Advisory Committee Meeting March 22, 2010. Silver Spring: US Food and Drug Administration; 2010 [cited February 4, 2015]. Available from: http://www.fda.gov/downloads/AdvisoryCommittees/CommitteesMeetingMaterials/PediatricAdvisoryCommittee/ UCM205380.pdf. Accessed February 4, 2015.

122. Chanoine JP, Hampl S, Jensen C, Boldrin M, Hauptman J. Effect of orlistat on weight and body composition in obese adolescents: a randomized controlled trial. JAMA. 2005;293(23):2873-2883.

123. McDuffie JR, Calis KA, Uwaifo GI, et al. Efficacy of orlistat as an adjunct to behavioral treatment in overweight African American and Caucasian adolescents with obesity-related co-morbid conditions. J Pediatr Endocrinol Metab. 2004;17(3):307-319.

124. Park MH, Kinra S, Ward KJ, White B, Viner RM. Metformin for obesity in children and adolescents: a systematic review. Diabetes Care. 2009;32(9):1743-1745.

125. Sjöström L, Narbro K, Sjöström CD, et al. Effects of bariatric surgery on mortality in Swedish obese subjects. N Engl J Med. 2007;357(8): 741-752.

126. Inge TH, Miyano G, Bean J, et al. Reversal of type 2 diabetes mellitus and improvements in cardiovascular risk factors after surgical weight loss in adolescents. Pediatrics. 2009;123(1):214-222.

127. Silva GM, Osório A, Pereira F, et al. Effect of laparoscopic adjustable gastric banding on modifiable cardiovascular risk factors in extremely obese adolescents. Obes Surg. 2012;22(6):991-994.

128. Rocchini AP, Key J, Bondie D, et al. The effect of weight loss on the sensitivity of blood pressure to sodium in obese adolescents. $N$ Engl J Med. 1989;321(9):580-585.

129. Arnberg K, Larnkjær A, Michaelsen KF, Jensen SM, Hoppe C, Mølgaard C. Casein improves brachial and central aortic diastolic blood pressure in overweight adolescents: a randomised, controlled trial. J Nutr Sci. 2014;2:e43. 
130. Pal S, Ellis V. The chronic effects of whey proteins on blood pressure, vascular function, and inflammatory markers in overweight individuals. Obesity (Silver Spring). 2010;18(7):1354-1359.

131. Franklin SS, Larson MG, Khan SA, et al. Does the relation of blood pressure to coronary heart disease risk change with aging? The Framingham Heart Study. Circulation. 2001;103(9):1245-1249.

132. Couch SC, Saelens BE, Levin L, Dart K, Falciglia G, Daniels SR. The efficacy of a clinic-based behavioral nutrition intervention emphasizing a DASH-type diet for adolescents with elevated blood pressure. J Pediatr. 2008;152(4):494-501.

133. Halbach SM, Flynn J. Treatment of obesity-related hypertension in children and adolescents. Curr Hypertens Rep. 2013;15(3):224-231.

134. Soletsky B, Feig DI. Uric acid reduction rectifies prehypertension in obese adolescents. Hypertension. 2012;60(5):1148-1156.

135. Song YH. The correlation of blood pressure with height and weight in Korean adolescents aged 10-19 years; The Korean National Health and Nutrition Examination Surveys (2009-2011). Korean J Pediatr. 2014;57(1):35-40.

136. Abdul Razzak R, Elmteri A, Elkanderi T, et al. Preliminary blood pressure screening in a representative sample of extremely obese Kuwaiti adolescents. J Obes. 2013;2013:968754.

137. Duncan MJ, Mota J, Vale S, Santos MP, Ribeiro JC. Associations between body mass index, waist circumference and body shape index with resting blood pressure in Portuguese adolescents. Ann Hum Biol. 2013;40(2):163-167.

138. Kim NY, Hong YM, Jung JW, Kim NS, Noh CI, Song YH. The relationships of body mass index, waist-to-height ratio, and body fat percentage with blood pressure and its hemodynamic determinants in Korean adolescents: a school-based study. Korean J Pediatr. 2013;56(12): 526-533.
139. Mehdad S, Hamrani A, El Kari K, et al. Prevalence of elevated blood pressure and its relationship with fat mass, body mass index and waist circumference among a group of Moroccan overweight adolescents. Obes Res Clin Pract. 2013;7(4):e284-e289.

140. Pecin I, Samovojska R, Heinrich B, Zeljković-Vrkić T, Laganović M, Jelaković B. Hypertension, overweight and obesity in adolescents: the CRO-KOP study. Coll Antropol. 2013;37(3):761-764.

141. Rutkowski B, Czarniak P, Król E, Szcześniak P, Zdrojewski T. Overweight, obesity, hypertension and albuminuria in Polish adolescents - results of the Sopkard 15 study. Nephrol Dial Transplant. 2013; 28 Suppl 4:iv204-iv211.

142. Ying-Xiu Z, Zhao-Xia W, Ling Y, Chun-Bo G, Yu-Lin G. Association between body mass index, skinfold thickness and blood pressure in 12-year-old children. Eur J Pediatr. 2013;172(9):1167-1171.

143. Duncan MJ, James L, Griffiths L. The relationship between resting blood pressure, body mass index and lean body mass index in British children. Ann Hum Biol. 2011;38(3):324-329.

144. Larsson $\mathrm{C}$, Hernell $\mathrm{O}$, Lind $\mathrm{T}$. Moderately elevated body mass index is associated with metabolic variables and cardiovascular risk factors in Swedish children. Acta Paediatr. 2011;100(1):102-108.

145. Salvi P, Meriem C, Temmar M, et al. Association of current weight and birth weight with blood pressure levels in Saharan and European teenager populations. Am J Hypertens. 2010;23(4):379-386.

146. Guimarães IC, de Almeida AM, Santos AS, Barbosa DB, Guimarães AC. Blood pressure: effect of body mass index and of waist circumference on adolescents. Arq Bras Cardiol. 2008;90(6):393-399.

147. Caprio S, Hyman LD, McCarthy S, Lange R, Bronson M, Tamborlane WV. Fat distribution and cardiovascular risk factors in obese adolescent girls: importance of the intraabdominal fat depot. Am J Clin Nutr. 1996;64(1):12-17. 


\section{Supplementary materials}

Table SI Factors associated with the development of hypertension in overweight adolescents

\begin{tabular}{|c|c|c|c|}
\hline Factors & Publication & Year & Effect in overweight adolescents \\
\hline \multicolumn{4}{|l|}{ Nonmodifiable factors } \\
\hline \multirow[t]{2}{*}{ Age } & La Manna et al ${ }^{1} *$ & 1982 & Age $>13$ years associated with hypertension. \\
\hline & Siklar et $\mathrm{al}^{2}$ & 2011 & Older age associated with hypertension. \\
\hline \multirow[t]{3}{*}{ Sex } & Koenigsberg et $\mathrm{al}^{3, *}$ & 2006 & Hypertension more likely in males $>11$ years. \\
\hline & La Manna et al ${ }^{1} *$ & 1982 & Hypertension more likely in females. \\
\hline & Hannon et $\mathrm{al}^{4}$ & 2015 & Not significant. \\
\hline \multirow[t]{4}{*}{ Ethnicity } & Harding et $\mathrm{al}^{5, *}$ & 2008 & Indian participants had higher risk of hypertension. \\
\hline & Martin et $a^{6}$ & 2015 & $\begin{array}{l}\text { Turkish participants had a higher risk of hypertension whereas Central European } \\
\text { participants had a lower risk. }\end{array}$ \\
\hline & Puri et $\mathrm{al}^{7, *}$ & 2008 & $\begin{array}{l}\text { African American and Caribbean Hispanic had a higher risk compared to white } \\
\text { participants. }\end{array}$ \\
\hline & Hannon et $\mathrm{al}^{4}$ & 2015 & $\begin{array}{l}\text { African American and Hispanic participants had a higher risk of hypertension } \\
\text { compared to white participants. }\end{array}$ \\
\hline \multirow[t]{6}{*}{ Genetics } & Siklar et al ${ }^{2}$ & 2011 & ACE I/D polymorphism not significant. \\
\hline & Santoro et al ${ }^{8}$ & 2008 & $\begin{array}{l}\text { The presence of certain } Y 2 R \text { gene variants ( } T \text { allele and } T 585 \text { allele) was } \\
\text { protective for hypertension. Other } Y 2 R \text { gene variants }(C C \text { and } C T \text { ) were } \\
\text { associated with higher risk of hypertension. }\end{array}$ \\
\hline & Souza-Costa et al ${ }^{9}$ & 2011 & The eNOS haplotype C b Glu is associated with hypertension. \\
\hline & Faienza et $\mathrm{al}^{10}$ & 2010 & $\begin{array}{l}\text { IGF2 gene variants ( } 6815 \mathrm{~A} / \mathrm{T} \text { and } \mathrm{T} 68 \mathrm{I} 5) \text { are associated with higher risk of } \\
\text { hypertension, IGF2 variant } \mathrm{A} 68 \mathrm{I} 5 \text { allele is associated with lower risk. }\end{array}$ \\
\hline & Lemes et $\mathrm{al}^{\prime \prime}$ & 2013 & ACE I/D polymorphism is associated with hypertension in males only. \\
\hline & Guerra et $\mathrm{al}^{12}$ & 2003 & ApoE polymorphism not significant. \\
\hline \multirow[t]{3}{*}{ Family history of hypertension } & Nishina et $\mathrm{al}^{13}$ & 2003 & Family history of hypertension not significant. \\
\hline & La Manna et al' & 1982 & Family history of hypertension associated with hypertension. \\
\hline & Siklar et $\mathrm{a}^{2}$ & 2011 & Family history of hypertension associated with hypertension. \\
\hline Family history of diabetes & La Manna et al' & 1982 & Family history of diabetes associated with hypertension. \\
\hline \multirow[t]{2}{*}{ Low birth weight } & Lurbe et al ${ }^{14, *}$ & 2009 & Lower birth weight associated with higher systolic BP values. \\
\hline & Strufaldi et al ${ }^{15}$ & 2009 & $\begin{array}{l}\text { Risk of hypertension significantly higher in those with both low birth weight and } \\
\text { current obesity. }\end{array}$ \\
\hline Pubertal status & Siklar et $\mathrm{al}^{2}$ & 2011 & $\begin{array}{l}\text { Participants who were pubertal or postpubertal were more likely to have } \\
\text { hypertension. }\end{array}$ \\
\hline \multicolumn{4}{|l|}{ Modifiable factors } \\
\hline Physical activity & Hayes et al ${ }^{16}$ & 2013 & Physical activity did not attenuate blood pressure risk. \\
\hline \multirow[t]{4}{*}{ Cardiorespiratory fitness } & Nielsen et $\mathrm{al}^{17}$ & 2003 & $\begin{array}{l}\text { BMI was a stronger predictor of hypertension in female individuals with low } \\
\text { fitness levels. Higher fitness levels were associated with lower risk. }\end{array}$ \\
\hline & Eisenmann et $\mathrm{al}^{18}$ & 2007 & $\begin{array}{l}\text { Those with both elevated BMI and low fitness had the highest levels of } \\
\text { metabolic syndrome. }\end{array}$ \\
\hline & Shaibi et al ${ }^{19}$ & 2005 & $\mathrm{VO}_{2}$ max is not associated with any individual risk factors in overweight youth. \\
\hline & Marcelino et $\mathrm{a}^{20}$ & 2012 & $\begin{array}{l}\text { High cardiorespiratory fitness is protective for hypertension in those with high } \\
\text { body fat but not high BMI. }\end{array}$ \\
\hline \multirow[t]{2}{*}{ Sedentary behaviors } & Pardee et $\mathrm{a}^{21}$ & 2007 & Hypertension in obese children is associated with time spent watching television. \\
\hline & Goldfield et a ${ }^{22, *}$ & 2011 & $\begin{array}{l}\text { In obese adolescents, time spent playing video games was independently } \\
\text { associated with hypertension. }\end{array}$ \\
\hline Sleep & Hannon et $\mathrm{al}^{4}$ & 2015 & Lack of REM sleep is associated with hypertension. \\
\hline
\end{tabular}

Note: *Denotes studies that present effective estimates in adolescents only.

Abbreviations: ACE IID, angiotensin converting enzyme insertion/deletion; BP, blood pressure; BMI, body mass index; eNOS, endothelial nitric oxide synthase; IGF2, insulin-like growth factor; REM, rapid eye movement; $\mathrm{VO}_{2}$ max, maximal oxygen uptake; $Y 2 R$, $Y 2$ receptor; ApoE, apolipoprotein $\mathrm{E}$. 
Table S2 Subclinical markers associated with hypertension in overweight adolescents

\begin{tabular}{|c|c|}
\hline Biochemical marker & Publications \\
\hline Hypercholesterolemia & Glowinska et $\mathrm{a}^{23}$ \\
\hline High LDL & Glowinska et $\mathrm{a}^{23}$ \\
\hline Hypertriglyceridemia & Siklar et $\mathrm{al}^{2}$ \\
\hline High triglyceride/HDL cholesterol ratio & Siklar et $\mathrm{al}^{2}$ \\
\hline Low HDL & Siklar et $\mathrm{al}^{2}$ \\
\hline Hyperinsulinemia & Nishina et al $;^{13}$ Libman et al ${ }^{24}$ Csabi et $\mathrm{al}^{25}$ \\
\hline Low adiponectin & De Las Heras et al; ${ }^{26, *}$ Lezhenko et $\mathrm{al}^{27, *}$ Shatat et al $\mathrm{a}^{28, *}$ \\
\hline High leptin & Tu et al; $;^{29}$ Nishina et al $;{ }^{13}$ Hirose et $\mathrm{a}^{30, *}$ \\
\hline High NT-proBNP (males only) & Pervanidou et $\mathrm{al}^{31, *}$ \\
\hline High osteopontin & Lezhenko et $\mathrm{al}^{27}$ \\
\hline High aldosterone & Rocchini et al; ${ }^{32, *}$ Shatat et $\mathrm{al}^{33, *}$ \\
\hline Low plasma renin & Shatat et $\mathrm{a}^{33, *}$ \\
\hline High CRP & Noronha et a $\left.\right|^{34}$ \\
\hline Microalbuminuria & Nguyen et $\mathrm{al}^{35, *}$ \\
\hline High IR-HOMA & Siklar et $\mathrm{al}^{2}$ \\
\hline
\end{tabular}

Note: *Denotes studies that present effective estimates in adolescents only.

Abbreviations: CRP, C-reactive protein; HDL, high-density lipoprotein; LDL, low-density lipoprotein; NT-proBNP, n-terminal pro-brain natriuretic peptide; IR-HOMA, insulin resistance homeostasis model assessment.

\section{References}

1. La Manna A, Spagnoletti T, Galizia G, Ponticiello L, De Luca R. [Statistical analysis of risk factors for hypertension in obese children]. Boll Soc Ital Biol Sper. 1982;58(5):253-258. Italian.

2. Siklar Z, Berberoglu M, Savas Erdeve S, et al. Contribution of clinical, metabolic, and genetic factors on hypertension in obese children and adolescents. J Pediatr Endocrinol Metab. 2011;24(1-2):21-24.

3. Koenigsberg J, Boyd GS, Gidding SS, Hassink SG, Falkner B. Association of age and sex with cardiovascular risk factors and insulin sensitivity in overweight children and adolescents. J Cardiometab Syndr. 2006;1(4):253-258.

4. Hannon TS, Gupta S, Li Z, et al. The effect of body mass index on blood pressure varies by race among obese children. $J$ Pediatr Endocrinol Metab. 2015;28(5-6):533-538.

5. Harding S, Maynard MJ, Cruickshank K, Teyhan A. Overweight, obesity and high blood pressure in an ethnically diverse sample of adolescents in Britain: the Medical Research Council DASH study. Int J Obes (Lond). 2008;32(1):82-90.

6. Martin L, Oepen J, Reinehr T, et al. Ethnicity and cardiovascular risk factors: evaluation of 40,921 normal-weight, overweight or obese children and adolescents living in Central Europe. Int J Obes (Lond). 2015;39(1):45-51.

7. Puri M, Flynn JT, Garcia M, Nussbaum H, Freeman K, DiMartino-NardiJR. The frequency of elevated blood pressure in obese minority youth. J Clin Hypertens (Greenwich). 2008;10(2):119-124.

8. Santoro N, Del Giudice EM, Grandone A, et al. Y2 receptor gene variants reduce the risk of hypertension in obese children and adolescents. J Hypertens. 2008;26(8):1590-1594.

9. Souza-Costa DC, Belo VA, Silva PS, et al. eNOS haplotype associated with hypertension in obese children and adolescents. Int J Obes (Lond). 2011;35(3):387-392.

10. Faienza MF, Santoro N, Lauciello R, et al. IGF2 gene variants and risk of hypertension in obese children and adolescents. Pediatr Res. 2010; 67(4):340-344.

11. Lemes VA, Neves AL, Guazzelli IC, Frazzatto E, Nicolau C, CorreaGiannella ML, et al. Angiotensin converting enzyme insertion/deletion polymorphism is associated with increased adiposity and blood pressure in obese children and adolescents. Gene. 2013;532(2):197-202.

12. Guerra A, Rego C, Castro EM, Seixas S, Rocha J. Influence of apolipoprotein e polymorphism on cardiovascular risk factors in obese children. Ann Nutr Metab. 2003;47(2):49-54.

13. Nishina M, Kikuchi T, Yamazaki H, Kameda K, Hiura M, Uchiyama M. Relationship among systolic blood pressure, serum insulin and leptin, and visceral fat accumulation in obese children. Hypertens Res. 2003;26(4):281-288.
14. Lurbe E, Carvajal E, Torro I, Aguilar F, Alvarez J, Redon J. Influence of concurrent obesity and low birth weight on blood pressure phenotype in youth. Hypertension. 2009;53(6):912-917.

15. Strufaldi MW, Silva EM, Franco MC, Puccini RF. Blood pressure levels in childhood: probing the relative importance of birth weight and current size. Eur J Pediatr. 2009;168(5):619-624.

16. Hayes HM, Eisenmann JC, Pfeiffer K, Carlson JJ. Weight status, physical activity, and vascular health in 9- to 12-year-old children. $J$ Phys Act Health. 2013;10(2):205-210.

17. Nielsen GA, Andersen LB. The association between high blood pressure, physical fitness, and body mass index in adolescents. Prev Med. 2003;36(2):229-234

18. Eisenmann JC, Welk GJ, Wickel EE, Blair SN. Combined influence of cardiorespiratory fitness and body mass index on cardiovascular disease risk factors among 8-18 year old youth: The Aerobics Center Longitudinal Study. Int J Pediatr Obes. 2007;2(2):66-72.

19. Shaibi GQ, Cruz ML, Ball GD, Weigensberg MJ, Kobaissi HA, Salem GJ, et al. Cardiovascular fitness and the metabolic syndrome in overweight latino youths. Med Sci Sports Exerc. 2005;37(6):922-928.

20. Marcelino G, Melich-Cerveira J, Paccaud F, Marques-Vidal P. Obese and fit adolescents have lower blood pressure levels than obese and unfit counterparts. J Sports Med Phys Fitness. 2012;52(6):639-646.

21. Pardee PE, Norman GJ, Lustig RH, Preud'homme D, Schwimmer JB. Television viewing and hypertension in obese children. Am J Prev Med. 2007;33(6):439-443.

22. Goldfield GS, Kenny GP, Hadjiyannakis S, et al. Video game playing is independently associated with blood pressure and lipids in overweight and obese adolescents. PLoS One. 2011;6(11):e26643.

23. Glowinska B, Urban M, Koput A. Cardiovascular risk factors in children with obesity, hypertension and diabetes: lipoprotein(a) levels and body mass index correlate with family history of cardiovascular disease. Eur J Pediatr. 2002;161(10):511-518.

24. Libman IM, Barinas-Mitchell E, Bartucci A, Chaves-Gnecco D, Robertson R, Arslanian S. Fasting and 2-hour plasma glucose and insulin: relationship with risk factors for cardiovascular disease in overweight nondiabetic children. Diabetes Care. 2010;33(12):2674-2676.

25. Csabi G, Molnár D, Hartmann G. Urinary sodium excretion: association with hyperinsulinaemia, hypertension and sympathetic nervous system activity in obese and control children. Eur J Pediatr. 1996;155(10): 895-897.

26. De Las Heras J, Lee S, Bacha F, Tfayli H, Arslanian S. Cross-sectional association between blood pressure, in vivo insulin sensitivity and adiponectin in overweight adolescents. Horm Res Paediatr. 2011;76(6): 379-385. 
27. Lezhenko G, Gladun E. [The role of osteopontin and adiponectin in the development of insulin resistance and hypertension in obesed adolescents]. Georgian Med News. 2013;(214):43-48. Russian.

28. Shatat IF, Freeman KD, Vuguin PM, Dimartino-Nardi JR, Flynn JT. Relationship between adiponectin and ambulatory blood pressure in obese adolescents. Pediatr Res. 2009;65(6):691-695.

29. Tu W, Eckert GJ, DiMeglio LA, Yu Z, Jung J, Pratt JH. Intensified effect of adiposity on blood pressure in overweight and obese children. Hypertension. 2011;58(5):818-824.

30. Hirose H, Saito I, Tsujioka M, Mori M, Kawabe H, Saruta T. The obese gene product, leptin: possible role in obesity-related hypertension in adolescents. J Hypertens. 1998;16(12 Pt 2):2007-2012.

31. Pervanidou P, Akalestos A, Sakka S, Kanaka-Gantenbein C, Papassotiriou I, Chrousos GP. Gender dimorphic associations between N-terminal pro-brain natriuretic peptide, body mass index and blood pressure in children and adolescents. Horm Res Paediatr. 2010;73(5): $341-348$.
32. Rocchini AP, Katch VL, Grekin R, Moorehead C, Anderson J. Role for aldosterone in blood pressure regulation of obese adolescents. Am J Cardiol. 1986;57(8):613-618.

33. Shatat IF, Flynn JT. Relationships between renin, aldosterone, and 24-hour ambulatory blood pressure in obese adolescents. Pediatr Res. 2011;69(4):336-340.

34. Noronha JA, Medeiros CC, Cardoso Ada S, Gonzaga NC, Ramos AT, Ramos AL. C-reactive protein and its relation to high blood pressure in overweight or obese children and adolescents. Rev Paul Pediatr. 2013;31(3):331-337.

35. Nguyen S, McCulloch C, Brakeman P, Portale A, Hsu CY. Being overweight modifies the association between cardiovascular risk factors and microalbuminuria in adolescents. Pediatrics. 2008;121(1):37-45.
Adolescent Health, Medicine and Therapeutics

\section{Publish your work in this journal}

Adolescent Health, Medicine and Therapeutics is an international, peer-reviewed, open access journal focusing on health, pathology, and treatment issues specific to the adolescent age group. All aspects of health maintenance, preventative measures and disease treatment interventions are addressed within the journal and practitioners from

\section{Dovepress}

all disciplines are invited to submit their work as well as healthcare researchers and patient support groups.. The manuscript management system is completely online and includes a very quick and fair peerreview system. Visit http://www.dovepress.com/testimonials.php to read real quotes from published authors.

Submit your manuscript here: http://www.dovepress.com/adolescent-health-medicine-and-therapeutics-journal 